\title{
THE EFFECT OF EARNINGS VOLATILITY ON BORROWERS' COST OF DEBT: EVIDENCE FROM INDONESIA
}

\author{
Goldia Liku Sirupang Pongrangga \\ Universitas Atma Jaya Yogyakarta, Indonesia \\ Email: goldialiku1@gmail.com \\ Anggreni Dian Kurniawati \\ Universitas Atma Jaya Yogyakarta, Indonesia \\ Email:anggreni.kurniawati@uajy.ac.id
}

Received: September 2019; Accepted: December 2019; Available online: January 2020

\begin{abstract}
This study aims to examine the effect of earnings volatility on borrowers cost of debt. In addition, this study also analyzes the difference effect of earnings volatility on borrowers' cost of debt for different industries. Samples are selected by using the purposive sampling method and obtained 1,100 observations from eight industries sector in Indonesia listed in Indonesian Stock Exchange based on the Jakarta Stock Industrial Classification from 20122016. Three control variables used in this study were profitability, liquidity and solvency. The result shows that earnings volatility has positive effect on the borrowers' cost of debt. The profitability has a negative effect on borrowers' cost of debt, nevertheless liquidity and solvency have no effect on borrowers cost of debt. Therefore, every company expected to maintain and stabilize their earnings with generates a good performance of profitability. Furthermore, the result also shows that there is a difference effect of earnings volatility on borrowers' cost of debt in each industrial sector in Indonesia listed in Indonesia Stock Exchange. The industrial sector which have significant effects between earnings volatility and borrowers' cost of debt were agriculture sector and miscellaneous sector.
\end{abstract}

Keywords: borrowers' cost of debt, earnings volatility, liquidity, profitability, solvency

\begin{abstract}
Abstrak
Penelitian ini bertujuan untuk menguji pengaruh earnings volatility terhadap borrowers' cost of debt. Selain itu, penelitian ini juga menganalisis pengaruh perbedaan earnings volatility terhadap borrowers' cost of debt untuk tiap sektor industri. Sampel dipilih dengan menggunakan metode purposive sampling dan diperoleh 1.100 pengamatan dari delapan sektor industri di Indonesia yang terdaftar di Bursa Efek Indonesia berdasarkan Jakarta Stock Industrial Classification dari 2012-2016. Tiga variabel kontrol digunakan dalam penelitian ini yaitu profitabilitas, likuiditas dan solvabilitas. Hasil penelitian ini menunjukkan bahwa earnings volatility berpengaruh positif terhadap borrowers' cost of debt. Profitabilitas memiliki efek negatif pada borrowers' cost of debt, namun likuiditas dan solvabilitas tidak berpengaruh pada borrowers' cost of debt. Oleh karena itu, setiap perusahaan diharapkan untuk mempertahankan dan menstabilkan pendapatan mereka dengan menghasilkan kinerja profitabilitas yang baik. Selain itu, hasil juga menunjukkan bahwa ada perbedaan pengaruh earnings volatility terhadap borrowers' cost of debt di tiap sektor industri di Indonesia yang terdaftar di Bursa Efek Indonesia. Sektor industri yang memiliki pengaruh signifikan antara earnings volatility dan borrowers' cost of debt adalah sektor pertanian dan sektor lainnya.
\end{abstract}

Kata kunci: borrowers' cost of debt, earnings volatility, likuiditas, profitabilitas, solvabilitas.

How to Cite: Pongrangga, G. L. S., \& Kurniawati, A. D. (2020). Effect of Earnings Volatility on Borrowers Cost of Debt: Evidence from Indonesia. Media Ekonomi dan Manajemen, 35(1), 19-33. doi: http://dx.doi.org/10.24856/mem.v35i1.1196. 


\section{INTRODUCTION}

The government of Indonesia experienced the rise of debt since the general election in 2019. Since Joko Widodo ran the presidency in 2015, the government has experienced almost two times on the debt level than the previous government. The data from Financial Ministry of Indonesia (2019), the additional debt that the government has been allocated to the funding of productive activities such as infrastructure projects, welfare fund, health program, education, tax expenditure and pooling fund for disaster. This is very common in the government demands fund by means of debt for its citizen and this matter naturally happened in the company. The company demands for fund to starting up the business, expand the business and making a business profit. Fund also an important aspect for supporting business ease of doing for operational and non-operational activities, so the needs for fund become unlimited. In several business cases, debt might be an alternative due to this situation.

In running a business, the smallscale companies up to the large-scale companies certainly have debts as a part of their additional equity and funding source for the needs to be going concern and solvable. Debt is the responsibility of a company that has been incurred by a past transaction and has to be settled by means of cash, goods, and service in the future (Jusup, 2001). Companies tend to choose for debts than sales of securities or cash flow because it has lower cost although the companies should provide the return to lenders. The fund that lenders have provided for the companies will incur certain cost known as the cost of debt. Cost of debt refers to the level of return prior to tax that should be paid to the lender (Nurauliawati, 2010). Cost of debt also defined as the effective rate that a company should pay within the debt that the company has from the other financial institutions or sources such as bond or loan. Furthermore, the cost of debt is usually intended to define the best interest rate for funding the company. The cost of debt itself might also be used for measuring the company risk because a company that has high risk suffered from high cost of debt, control concentration responds to factors that amplify or weaken its effects on the cost of debt, such as the quality of investment opportunities, tangible asset intensity, financial market development, and the strength of investor rights. The strategic actions by selfinterested dominant shareholders are a major source of corporate credit risk (Aslan \& Kumar, 2012).

In such debt system, there is several criteria that should be met by the creditor in order to have a debt. There are five criteria that known as five C's. The five C's of credit is a system used by lenders to gauge the creditworthiness of potential borrowers. The system weighs five characteristics of the borrower and conditions of the loan, attempting to estimate the chance of default. The five C's of credit are character, capacity, capital, collateral and conditions (Huq, 2016). Most of the information that lenders need for assessing the criteria of the creditors can be found on the financial statement. Most of the lenders assume that the information of earnings in a financial statement is important in order to identify the earnings quality and the company's debt sufficiency. The earnings that has been found on the financial statement might also be used for evaluating the performance of the management, predicting the earnings power, and predicting the future earnings (Siallagan \& Mas'ud, 2006). Both the creditors and the lenders do not expect the information of earnings is low-qualified because it might be a signal for the poor resource allocation. This means that the earnings might be one of the criteria for the lenders in granting the debt to the creditors. On the other hand, the well-qualified earnings are assessed 
based on the condition of earnings is steady or volatile over the time. In steady or volatile condition, the earnings will reflect the bad condition of the company performance. Therefore, such conditions will affect the assessment of both the lenders and the investors over the company. The low earnings volatility reflects a positive aspect and increase the reliability of the financial report (Cohen, 2003).

The financial analyst and investor have a different perspective to reduce the cost of debt. In financial analyst side, there are two main reasons. First, the information contained in financial analyst forecasts play a key role to mitigating information asymmetry between firms and market participants. Second, information production by analyst serves to monitor managers by imposing market discipline from the information revealed in their earnings forecast (Mansi, Maxwell, \& Miller, 2011). In the other hand, investor can reduce the cost of debt with the decision-making process. If the investor makes an analysis with the financial information from the firm to make investment decision accurately, it can impact to the market price and the implication is it can reduce the earnings volatility. If the earnings become stable, it can increase the earnings quality and reduce the borrowers' cost of debt. Furthermore, it is important to analyze the effect of earning volatility to borrowers' cost of debt so the investor can have a complete picture of firm performance to make an accurate decision making. Investor expectations and financial reporting have been largely ignored by researchers, resulting in an unexplained bias present within the financial accounting decision making process. This unknown bias has resulted in investors receiving an incomplete picture of firm performance as well as inaccurate information regarding the success of the implemented firm strategies. As such, without research to provide awareness of the plausible association between business strategy and earnings quality, investors will continue to be misled (Houqe, Kerr, \& Monem, 2013).

Creditor and investor consider three main criteria in determining the interest rate or borrowers' cost of debt such as profitability, liquidity and solvability. Moreover, there are other factors that can show the feasibility of borrowers which can be seen from the company's capacity to run its business. The business strength can be seen from the earnings. However, the research questions that discuss in this research such as: does the borrower's earnings have good and stable prospects? If earnings are not stable enough, do lenders consider it to be the factor that can affect giving of debt for the borrower? If the company have good and stable earnings, whether this condition will affect borrowers' cost of debt? This problem leads to the research gap about the effect of earnings volatility on borrowers' cost of debt because from the previous research, it is found that the research related to earning volatility and borrowers' cost of debt have been very limited. Hence, the aim of this research is to examine the effect of earnings volatility to borrowers' cost of debt. This research will make significant contribution to understand how relevant is earnings volatility for borrowers' cost of debt in Indonesia.

\section{LITERATURE REVIEW}

A fundamental role of financial reporting is to serve as a basis for capital allocation. However, the quality of reported earnings is influenced by a firm's fundamentals such as its operating environment and business model as well as by the discretionary reporting choices made by the managers. To the extent investors differ in their ability to process this information, poor earnings quality can lead to differentially informed investors. Higher information asymmetry is costly as 
it increases the adverse selection risk for market participants and lowers liquidity. For these reasons, standard setters and regulators are concerned about the quality of accounting information and its consequences for capital allocation decisions (Bhattacharya, Desai, \& Venkataraman, 2015).

Capital allocation decisions are use to increase company efficiency and maximize its profits, so a company's success or failure depend on it. Management allocate its capital and generate as much wealth as possible for its shareholders and consider the viability of the available investment options, evaluate each one's potential effects on the firm, and allocate the additional funds appropriately and in a manner that will produce the best overall results for the firm. Because the management must report the best effort for increasing the company profits to the principal, they typically engage in income smoothing to increase earnings in periods that would otherwise have unusually low earnings. Income smoothing is the shifting of revenue and expenses among different reporting periods in order to present the false impression that a business has steady earnings. Companies with high amount of creditor finance tend to report smoother earnings trends. The relationship to be stronger for bank credit compared to trade credit for the observed determinants. In countries with relatively weak debt contracts creditors have a stronger preference for smooth earnings. If a company has many creditors, it means that the company is able to gain trust and attract the creditor's attention through their good performance which can be seen from earnings quality. Smoother earnings lowers cost of debt, therefore earnings volatility should increase cost of debt (Trueman \& Titman, 1988).

The importance of earnings volatility for rating agencies suggests existence of incentives for managers to reduce earnings volatility in order to improve or maintain credit ratings. Longterm financial reporting strategies that managers use to impact perceptions of credit risk. It is among the first to examine reporting strategies in a setting where companies with stronger incentives to manage earnings to affect debt ratings can be identified ex ante (Soderstrom, Jung, \& Yang, 2012). The suppliers also prefer low volatility and firms with more predictable earnings had more access to supplier credit (Gassen \& Fulbier, 2015). This leads to the following hypothesis:

\section{$\mathbf{H}_{1}$ : Earnings volatility have a positive effect to the borrowers' cost of debt.}

Earnings volatility is one of the key determinants of risk and market price of a stock because it refers to how stable, or unstable, the earnings of a corporation are. A company whose has great earnings volatility means that it has a risky investment. Such volatile earnings make it very hard for management to plan ahead, especially when funds must be borrowed for long-term investments. Therefore, management try not only to maximize earnings, but also to make its look steady. Hence, management have a different plan and strategies to manage their earnings, the effects of earning volatility can varies across industrial sector. Earnings quality largely depends on the segment that the firm is operating (Dechow, Ge, \& Schrand, 2010 in Graham \& Dodd, 1934). Both cultural values and institutional structure have explanatory power for the earnings management around the world and the effect of both factors on earnings management is conditional on each other (Han et.al., 2010). The presence of earnings management practices in Malaysian industries, but the prevalence of earnings management activity and the motivation to do so are found to differ across industries. Industry competitiveness, capital intensity and profitability are found to influence both motivations to manage earnings while industry leverage is found significant only in the case of 
motivation to manage earnings to avoid reporting losses. Earnings volatility and size are insignificant in influencing the propensity to manage earnings (Wasiuzzaman, Sahafzadeh, \& Rezaie, 2015). This leads to the following hypothesis:

\section{$\mathbf{H}_{2}$ : There is a difference of earnings volatility on borrowers' cost of debt across industrial sector.}

\section{RESEARCH METHOD}

Samples were selected by using the purposive sampling method and obtained 1,100 observations from eight industries sector in Indonesia listed in Indonesian Stock Exchange based on the Jakarta Stock Industrial Classification (JASICA) from 2012-2016. Research period begins from 2012 because Indonesia had faced global crisis in 2008 so the data might be distorted due to the economic depression. Therefore, year 2012 is considerate to have a normal financial condition. This research will be focused for all industrial sectors except banking, finance and insurance industries since they are on the lenders' side and this study is conducted based on borrowers' side. All companies listed actively is needed to consider its routine publicity and monitor its completeness. The data are provided by company's internet website, Indonesia Capital Market Directory (ICMD), and the annual report. The annual report was published on Indonesia Stock Exchange Website (www.idx.co.id).

In this research, we use three variables. There are independent, dependent and control variables. Control variable is variable that controlled the dependent and independent variable to minimize the effect of external variables. The purpose of using control variable is to handle factors that may or may not interfere the result analysis (Sekaran \& Roger, 2013). The independent variable in this research is earnings volatility (EV). Earnings volatility refers to how stable, or unstable company's earnings. A company who's the earnings is volatile is a risky investment. Such volatile earnings make it very hard for management to plan ahead. We use two proxies to measure earnings volatility, there are volatility of EBIT (Revenue - Expense excluding interest and tax) and volatility of EBITDA (Revenue Expense excluding interest, tax, depreciation and amortization). Cost of debt (COD) is a dependent variable. Cost of debt is the rate of return desired by creditors when providing funding to the company (Masri \& Martani, 2012). We measure the cost of debt with a ratio of financial cost divided by total liability. The control variables in this research is profitability measured by Return on Assets (ROA), liquidity measured by Current Ratio (CR) and Solvability measured by Debt Equity Ratio (DER). We use these three control variables to make an accurate association and reduce the result bias.

We use descriptive statistics to provide description of data that have been seen from the average value (mean), standard deviation, variance, maximum value, and minimum value. This analysis will further facilitate observations about the variables in this research such as Cost of Debt, volatility of EBIT, volatility of EBITDA, Profitability, Liquidity and Solvability. The data obtained will be analyze with classical assumption test. The classical assumption test is conducted in order to avoid data bias. Hypothesis is tested by conducting a multiple linear regression. A model used to support the regression in this research is the short panel data. The panel data is selected since a large number of companies is studied over a short-period of time as opposed to long panel data or time series data which studies a relatively smaller number of subjects over a very long period of time. One of the main advantages of using panel data is that it increases the precision in estimation thus increases the reliability of 
the results (Cameron and Trivedi, 2009). Other advantages include that panel data models allows to control for unobserved variables (variables that are not included in the model) and individual heterogeneity (Torres-Reyna, 2007). The following panel models will be used to study the relationship between Cost of Debt and Earnings Volatility.

$$
\begin{array}{r}
\text { Model 1: } \operatorname{COD}_{i \mathrm{it}+1}=\alpha_{\mathrm{i}}+\beta_{1} \mathrm{EBITV}_{\mathrm{it}}+\beta_{2} \\
\mathrm{ROA}_{\mathrm{it}}+\beta_{3} \mathrm{LR}_{\mathrm{it}}+\beta_{4} \mathrm{DER}_{\mathrm{it}}+\varepsilon_{\mathrm{it}}
\end{array}
$$

$$
\begin{aligned}
\text { Model 2: } & \mathrm{COD}_{\mathrm{it}+1}=\alpha_{\mathrm{i}}+\beta_{1} \text { EBITDAV }_{\mathrm{it}}+ \\
& \beta_{2} \mathrm{ROA}_{\mathrm{it}}+\beta_{3} \mathrm{LR}_{\mathrm{it}}+\beta_{4} \mathrm{DER}_{\mathrm{it}}+ \\
& \varepsilon_{\mathrm{it}}
\end{aligned}
$$

Each of the models has one timevariant independent variable and three time-variant control variables. The dependent variable COD will lead by one year since lenders are likely to use historical accounting information of the independent variable and control variables. Thus independent variables and control variables at time ' $t$ ' will be used to define COD at time ' $t+1$ ', thus COD leads by 1 for the analysis. Further in the model ' $i$ ' represents entity while ' $t$ ' represents time. ' $\alpha_{i}$ ' is the constant, ' $\varepsilon_{\mathrm{it}}$ ' is the error term and ' $\beta$ ' are the coefficient of the respective independent variables.

\section{RESULT AND DISCUSSION}

Descriptive statistics provides variable description in the research. Table 2 shows descriptive statistics result in research model for independent variable Earnings Volatility (volatility of EBIT and EBITDA), dependent variable Cost of Debt and control variables Profitability, Liquidity and Solvency.

Table 1 provides information that the number of samples processed in this research is 758 data. Cost of Debt as a dependent variable has a value range from 0.00 to 0.09 . The average value of Cost of
Debt is 0.0294 and standard deviation of 0.01903. As mentioned before, the independent variable divided into volatility of EBIT and volatility of EBITDA. From the result, EBITDA has higher standard deviation value for 0.00173 rather than EBIT and lower mean value for 0.0083 . EBIT has minimum value of 0.00 , maximum value of 2.02 , average value of 0.2630 and standard deviation of 0.32580 . Whereas EBITDA has minimum value of 0.00 , maximum value of 2.00 , average value of 0.2713 and standard deviation of 0.32753. Moreover, control variable Profitability has a value range from -13.23 to 66.00 and 7.07422 as the standard deviation. Profitability shows 6.9219 as the average number which means the companies earns an average profit 6,92\% of total asset. Therefore, Liquidity has minimum value of 0.01 and maximum value of 72.22 and standard deviation of 5.64416. Liquidity has the average value of 2.5361 means that most companies that researched are liquid because they have ability to pay their debts two times from the total debt. Solvency as the last control variable has a value range from -9.87 to 64.05, average number 1.5035 and standard deviation of 3.09961. Even though the average company has a good level of liquidity, the mean result of solvency turns out the level of long-term debt repayment is more than one time, which means that the company has more debt than capital.

This testing is the phase prior to the multiple linier regression analysis. We used to test the classic assumptions such as normality, multicollinearity, heteroscedasticity, and autocorrelation. The classic assumption test result is shown in Table 2.

Multiple regression analysis is used to test whether there is a significant effect between related variables. Multiple regression analysis result provided in Table 3.

The significance value of the $\mathrm{F}$ test in Table 4 is 0.000 , significance value of 
the Test $\mathrm{F}<0.05$ indicates that the EBIT regression equation model meets the Goodness of Fit. The significance value of EBIT volatility is 0.001 and the volatility of EBIT regression coefficient is 0.007 . The significance value is less than 0.05 and the regression coefficient is positive, meaning that the volatility of EBIT has a positive effect on the cost of debt or it can be concluded that Hypothesis 1 is accepted. Adjusted $\mathrm{R}$ Square value of 0.042 indicates that the volatility of EBIT, Profitability, Liquidity and Solvability can explain the change of Cost of Debt by $4.2 \%$ while the remaining $95.8 \%$ is influenced by other factors.

The significance value of the $\mathrm{F}$ test is 0.000 , the significance value of the Test $F$ $<0.05$ indicates that the EBITDA regression equation model meets the Goodness of Fit. The significance value of the volatility of EBITDA is 0.002 and the volatility of EBITDA regression coefficient is 0.007 . The significance value is less than 0.05 and the regression coefficient is positive, meaning that the volatility of EBITDA has a positive effect on the cost of debt or it can be concluded that Hypothesis 1 is accepted. Adjusted R Square value of 0.040 indicates that the volatility of EBITDA, Profitability, Liquidity and Solvability can explain the change of Cost of Debt by $4 \%$ while the remaining $96 \%$ is influenced by other factors.

Table 5 shows the multiple regression analysis result for volatility of EBIT and EBITDA for the most significant result across the industrial sector that are agriculture and miscellaneous sector.

Table 5 and 6 shows multiple regression analysis result of EBIT volatility and EBITDA volatility across industrial sectors. Agriculture sector is the only one industrial sector that have significant value less than 0.05. The significant value less than 0.05 means that EBIT volatility of agriculture sectors have significant effect on cost of debt compared with the other industrial sectors. The result shows there is a significant difference between associations of earnings volatility with cost of debt for different industrial sector or it can be concluded that Hypothesis 2 is accepted.

Table 1. Descriptive Statistics Result

\begin{tabular}{lrrrrc}
\hline & $\mathrm{N}$ & Minimum & Maximum & Mean & $\begin{array}{c}\text { Standard } \\
\text { Deviation }\end{array}$ \\
\hline Cost of Debt & 758 & 0.00 & 0.09 & 0.0294 & 0.01903 \\
Volatility Of EBIT & 758 & 0.00 & 2.02 & 0.2630 & 0.32580 \\
Volatility Of EBITDA & 758 & 0.00 & 2.00 & 0.2713 & 0.32753 \\
Profitability & 758 & -13.23 & 66.00 & 6.9219 & 7.07422 \\
Liquidity & 758 & 0.01 & 72.22 & 2.5361 & 5.64416 \\
Solvency & 758 & -9.87 & 64.05 & 1.5035 & 3.09961 \\
Valid N (listwise) & 758 & & & & \\
\hline
\end{tabular}


Table 2. Classic Assumption Test Results

\begin{tabular}{|c|c|c|c|c|}
\hline \multirow{2}{*}{ No } & \multirow{2}{*}{ Test } & \multicolumn{2}{|c|}{ Result } & \multirow{2}{*}{ Information } \\
\hline & & EBIT & EBITDA & \\
\hline 1. & Normality Test & $\begin{array}{l}\text { Asymp. Sig }>0.05 \\
\text { that is equal to } \\
0.055\end{array}$ & $\begin{array}{l}\text { Asymp. Sig }>0.05 \\
\text { that is equal to } \\
0.059\end{array}$ & $\begin{array}{l}\text { The data are } \\
\text { normally distributed. }\end{array}$ \\
\hline 2. & $\begin{array}{l}\text { Multicollinearity } \\
\text { Test }\end{array}$ & $\begin{array}{l}\text { Tolerance value } \\
\text { more than } 0.1 \text { and } \\
\text { VIF less than } 10\end{array}$ & $\begin{array}{l}\text { Tolerance value } \\
\text { more than } 0.1 \text { and } \\
\text { VIF less than } 10 .\end{array}$ & $\begin{array}{l}\text { There is no } \\
\text { multicollinearity } \\
\text { problem existed } \\
\text { between volatility of } \\
\text { EBIT and EBITDA } \\
\text { with the other } \\
\text { independent } \\
\text { variables. }\end{array}$ \\
\hline 3. & $\begin{array}{l}\text { Heteroscedasticity } \\
\text { Test }\end{array}$ & $\begin{array}{l}\text { If } \mathrm{c}^{2} \text { count }<\mathrm{c}^{2} \\
\text { table, means there is } \\
\text { no } \\
\text { heteroscedasticity. } \\
\text { The value of } \mathrm{c}^{2} \\
\text { count for EBIT is } \\
37,142 \text { dan the } \\
\text { value of } \mathrm{t}^{2} \text { table in } \\
\text { this study is } 822,12 \text {. } \\
\mathrm{C}^{2} \text { count value } \\
(37,142) \text { is bigger } \\
\text { than } \mathrm{c}^{2} \text { table } \\
(822,12)\end{array}$ & $\begin{array}{l}\text { If } \mathrm{c}^{2} \text { count }<\mathrm{c}^{2} \\
\text { table, means there is } \\
\text { no } \\
\text { heteroscedasticity. } \\
\text { The value of } \mathrm{c}^{2} \\
\text { count for EBITDA } \\
\text { is } 32,594 \text { dan the } \\
\text { value of } \mathrm{t}^{2} \text { table in } \\
\text { this study is } 822,12 \text {. } \\
\mathrm{C}^{2} \text { count value } \\
(32,594) \text { is bigger } \\
\text { than } \mathrm{c}^{2} \text { table } \\
(822,12)\end{array}$ & $\begin{array}{l}\text { There is no } \\
\text { heteroscedasticity. }\end{array}$ \\
\hline 4. & $\begin{array}{l}\text { Autocorrelation } \\
\text { Test }\end{array}$ & $\begin{array}{l}\text { Autocorrelation test } \\
\text { is using Durbin- } \\
\text { Watson decision. } \\
\text { For EBIT found that } \\
\text { DU is } 1.81 \text { and (4- } \\
\text { DU) is } 2.19 . \\
\text { Durbin-Watson } \\
\text { value here is } 1.839 \text {, } \\
\text { means it placed } \\
\text { between the range. }\end{array}$ & $\begin{array}{l}\text { EBITDA = DU is } \\
1.81 \text { and (4-DU) is } \\
2.19 . \text { Durbin- } \\
\text { Watson value here } \\
\text { is } 1.838, \text { means it } \\
\text { also placed between } \\
\text { the range. }\end{array}$ & $\begin{array}{l}\text { Both EBIT and } \\
\text { EBITDA results suits } \\
\text { the criteria of } \\
\text { Durbin-Watson } \\
\text { decision that no } \\
\text { autocorrelation } \\
\text { existed. }\end{array}$ \\
\hline
\end{tabular}


Table 3. Multiple Regression Analysis Result for Volatility of EBIT

\begin{tabular}{lccccc}
\hline & \multicolumn{2}{c}{$\begin{array}{c}\text { Unstandardized } \\
\text { Coefficients }\end{array}$} & $\begin{array}{c}\text { Standardized } \\
\text { Coefficients }\end{array}$ & & \\
\cline { 2 - 5 } Model & B & Std. Error & Beta & T & Sig. \\
\hline (Constant) & 0.030 & 0.001 & & 24.052 & 0.000 \\
Volatility of EBIT & 0.007 & 0.002 & 0.123 & 3.427 & 0.001 \\
Profitability (ROA) & 0.000 & 0.000 & -0.145 & -4.012 & 0.000 \\
Liquidity (CR) & 0.000 & 0.000 & -0.058 & -1.633 & 0.103 \\
Solvability (DER) & 0.000 & 0.000 & 0.040 & 1.110 & 0.268 \\
\hline Sig. F Test & 0.000 & & & & \\
\hline Adjusted R Square & 0.042 & & & & \\
\hline
\end{tabular}

Table 4. Multiple Regression Analysis Result for Volatility of EBITDA

\begin{tabular}{lccccc}
\hline & \multicolumn{2}{c}{$\begin{array}{c}\text { Unstandardized } \\
\text { Coefficients }\end{array}$} & $\begin{array}{c}\text { Standardized } \\
\text { Coefficients }\end{array}$ & & \\
\cline { 2 - 4 } Model & B & Std. Error & Beta & T & Sig. \\
\hline (Constant) & 0.030 & 0.001 & & 23.915 & 0.000 \\
Volatility of EBITDA & 0.007 & 0.002 & 0.114 & 3.173 & 0.002 \\
Profitability (ROA) & 0.000 & 0.000 & -0.146 & -4.056 & 0.000 \\
Liquidity (CR) & 0.000 & 0.000 & -0.059 & -1.660 & 0.097 \\
Solvability (DER) & 0.000 & 0.000 & 0.043 & 1.208 & 0.228 \\
\hline Sig. F Test & .000 & & & & \\
\hline Adjusted R Square & .040 & & & & \\
\hline
\end{tabular}

Table 5. Multiple Regression Analysis Result for Volatility of EBIT for Agriculture and Miscellaneous industry

\begin{tabular}{|c|c|c|c|}
\hline \multicolumn{4}{|c|}{ AGRICULTURE } \\
\hline Variable & $\begin{array}{c}\text { Standardized } \\
\text { Coefficients }\end{array}$ & Sig & Result \\
\hline EBIT Volatility & 0.023 & 0.017 & Significant \\
\hline Profitability & -0.002 & 0.064 & Not Significant \\
\hline Liquidity & 0.001 & 0.741 & Not Significant \\
\hline Solvency & -0.010 & 0.356 & Not Significant \\
\hline \multicolumn{4}{|c|}{ BASIC INDUSTRY AND CHEMICALS } \\
\hline Variable & $\begin{array}{c}\text { Standardized } \\
\text { Coefficients }\end{array}$ & Sig & Result \\
\hline EBIT Volatility & 0.003 & 0.437 & Not Significant \\
\hline Profitability & -0.001 & 0.005 & Significant \\
\hline Liquidity & 0.000 & 0.810 & Not Significant \\
\hline Solvency & 0.000 & 0.816 & Not Significant \\
\hline
\end{tabular}


Table 5. Continue

\begin{tabular}{lccc}
\hline \multicolumn{1}{c}{ Variable } & $\begin{array}{c}\text { Standardized } \\
\text { Coefficients }\end{array}$ & Sig & Result \\
\hline EBIT Volatility & 0.003 & 0.571 & Not Significant \\
Profitability & -0.001 & 0.047 & Significant \\
Liquidity & -0.001 & 0.268 & Not Significant \\
Solvency & 0.001 & 0.106 & Not Significant \\
\hline
\end{tabular}

\begin{tabular}{lccc}
\hline \multicolumn{4}{c}{ PROPERTY, REAL ESTATE AND BUILDING CONSTRUCTION } \\
\hline \multicolumn{1}{c}{ Variable } & $\begin{array}{c}\text { Standardized } \\
\text { Coefficients }\end{array}$ & Sig & Result \\
\hline EBIT Volatility & 0.006 & 0.112 & Not Significant \\
Profitability & -0.001 & 0.001 & Significant \\
Liquidity & -0.000 & 0.824 & Not Significant \\
Solvency & -0.001 & 0.396 & Not Significant \\
\hline
\end{tabular}

CONSUMER GOODS INDUSTRY

\begin{tabular}{lccc}
\hline \multicolumn{1}{c}{ Variable } & $\begin{array}{c}\text { Standardized } \\
\text { Coefficients }\end{array}$ & Sig & Result \\
\hline EBIT Volatility & -0.002 & 0.860 & Not Significant \\
Profitability & -0.001 & 0.000 & Significant \\
Liquidity & -0.002 & 0.137 & Not Significant \\
Solvency & 0.008 & 0.010 & Significant \\
\hline
\end{tabular}

\section{MISCELLANEOUS INDUSTRY}

\begin{tabular}{lccc}
\hline \multicolumn{1}{c}{ Variable } & $\begin{array}{c}\text { Standardized } \\
\text { Coefficients }\end{array}$ & Sig & Result \\
\hline EBIT Volatility & 0.011 & 0.047 & Significant \\
Profitability & 0.000 & 0.205 & Not Significant \\
Liquidity & 0.000 & 0.750 & Not Significant \\
Solvency & 0.000 & 0.799 & Not Significant \\
\hline
\end{tabular}

\section{TRADE, SERVICES \& INVESTMENT}

\begin{tabular}{lccc}
\hline \multicolumn{1}{c}{ Variable } & $\begin{array}{c}\text { Standardized } \\
\text { Coefficients }\end{array}$ & Sig & Result \\
\hline EBIT Volatility & 0.008 & 0.279 & Not Significant \\
Profitability & 0.000 & 0.669 & Not Significant \\
Liquidity & 0.000 & 0.197 & Not Significant \\
Solvency & 0.000 & 0.829 & Not Significant \\
\hline \multicolumn{4}{c}{ INFRASTRUCTURE, UTILITIES AND TRANSPORTATION } \\
\hline \multicolumn{1}{c}{ Variable } & Standardized & Sig & Result \\
\hline EBIT Volatility & Coefficients & 0.465 & Not Significant \\
Profitability & -0.007 & 0.578 & Not Significant \\
Liquidity & 0.000 & 0.009 & Significant \\
Solvency & -0.004 & 0.001 & Significant \\
\hline
\end{tabular}


Table 6. Multiple Regression Analysis Result for Volatility of EBITDA for Agriculture and Miscellaneous industry

\begin{tabular}{lccc}
\hline \multicolumn{1}{c}{ Variable } & $\begin{array}{c}\text { AGRICULTURE } \\
\text { Standardized } \\
\text { Coefficients }\end{array}$ & Sig & Result \\
\hline EBITDA Volatility & 0.017 & 0.045 & Significant \\
Profitability & -0.002 & 0.035 & Significant \\
Liquidity & -0.002 & 0.550 & Not Significant \\
Solvency & -0.013 & 0.271 & Not Significant \\
\hline
\end{tabular}

\begin{tabular}{lccc}
\hline \multicolumn{1}{c}{ BASIC INDUSTRY AND CHEMICALS } \\
\hline EBITDA Volatility & $\begin{array}{c}\text { Standardized } \\
\text { Coefficients }\end{array}$ & Sig & Result \\
Profitability & 0.007 & 0.290 & Not Significant \\
Liquidity & -0.001 & 0.004 & Significant \\
Solvency & 0.000 & 0.881 & Not Significant \\
\hline \multicolumn{5}{c}{ MINING } \\
\hline \multicolumn{1}{c}{ Variable } & 0.000 & 0.785 & Not Significant \\
\hline EBITDA Volatility & Standardized & Sig & Result \\
Profitability & 0.008 & 0.151 & Not Significant \\
Liquidity & -0.001 & 0.048 & Significant \\
Solvency & -0.001 & 0.351 & Not Significant \\
\hline
\end{tabular}

\begin{tabular}{|c|c|c|c|}
\hline \multicolumn{4}{|c|}{ PROPERTY, REAL ESTATE AND BUILDING CONSTRUCTION } \\
\hline Variable & $\begin{array}{c}\text { Standardized } \\
\text { Coefficients }\end{array}$ & Sig & Result \\
\hline EBITDA Volatility & 0.000 & 0.893 & Not Significant \\
\hline Profitability & -0.001 & 0.000 & Significant \\
\hline Liquidity & -0.000 & 0.738 & Not Significant \\
\hline Solvency & -0.001 & 0.212 & Not Significant \\
\hline \multicolumn{4}{|c|}{ CONSUMER GOODS INDUSTRY } \\
\hline Variable & $\begin{array}{l}\text { Standardized } \\
\text { Coefficients }\end{array}$ & Sig & Result \\
\hline EBITDA Volatility & 0.004 & 0.399 & Not Significant \\
\hline Profitability & 0.000 & 0.000 & Significant \\
\hline Liquidity & -0.002 & 0.127 & Not Significant \\
\hline Solvency & 0.007 & 0.019 & Significant \\
\hline
\end{tabular}


Table 6. Continue

\begin{tabular}{lccc}
\hline \multicolumn{1}{c}{ Mariable } & $\begin{array}{c}\text { Standardized } \\
\text { Coefficients }\end{array}$ & Sig & Result \\
\hline EBITDA Volatility & 0.004 & 0.416 & Not Significant \\
Profitability & 0.000 & 0.150 & Not Significant \\
Liquidity & 0.000 & 0.953 & Not Significant \\
Solvency & 0.000 & 0.989 & Not Significant \\
\hline
\end{tabular}

\begin{tabular}{lccc}
\hline \multicolumn{4}{c}{ TRADE, SERVICES \& INVESTMENT } \\
\hline \multicolumn{1}{c}{ Variable } & $\begin{array}{c}\text { Standardized } \\
\text { Coefficients }\end{array}$ & Sig & Result \\
\hline EBITDA Volatility & 0.011 & 0.104 & Not Significant \\
Profitability & 0.000 & 0.580 & Not Significant \\
Liquidity & 0.000 & 0.233 & Not Significant \\
Solvency & 0.000 & 0.839 & Not Significant \\
\hline
\end{tabular}

\begin{tabular}{lccc}
\hline \multicolumn{4}{c}{ INFRASTRUCTURE, UTILITIES AND TRANSPORTATION } \\
\hline \multicolumn{1}{c}{ Variable } & $\begin{array}{c}\text { Standardized } \\
\text { Coefficients }\end{array}$ & Sig & Result \\
\hline EBITDA Volatility & -0.005 & 0.996 & Not Significant \\
Profitability & 0.000 & 0.629 & Not Significant \\
Liquidity & -0.004 & 0.008 & Significant \\
Solvency & 0.006 & 0.002 & Significant \\
\hline
\end{tabular}

The results show that earnings volatility has a positive effect on borrowers' cost of debt. The higher earnings volatility caused higher cost of debt that will be paid by that company. Low volatility of company earnings can indicate that the company is able to achieve good performance (Trueman \& Titman, 1988). If the company's performance is good, the company's financial condition is in a stable position so that the company does not need to borrow funds from outside parties. In a good condition earning volatility will decrease and it is the good news to the investor because it reflects company's ability to maintain its going concern. In going concern condition, the company has free cash flow and tend to have an investment such as common stock or mutual fund rather than invest in debts such as bonds, loans and the other debt. Although the company can have an equity investment and decrease debt or being no debt at all, it must know the impact because these activities will affect the decreasing cost of debt. Therefore, according to the results, liquidity and solvability have a nonsignificant effect on borrowers' cost of debt. The results are consistent with the research of Prevost, et.al. (2008) and Huq (2016) which states that earnings volatility has a positive effect on cost of debt. Profitability, liquidity and solvability are the three control variables in this research. Based on the regression results, profitability has a negative effect on cost of debt, where the higher profitability of the company caused the lower cost of debt. This condition happened because when the company is able to generate a lot of profits, the company does not need to borrow from outside parties and does not bear the cost of debt. Billet, et.al. (2015) find that leverage increases in shareholder-manager misalignment because the increase in the 
cost of debt is less than the associated increase in the cost of equity. This would make debt more attractive relative to equity and reconcile the cost of debt and leverage results. This also points out the need to be cautious in interpreting higher leverage ratios as indicative of lower agency costs of debt.

The results also indicate that there is a difference in the effect of earnings volatility on cost of debt that occurs across industrial sector in Indonesia based on the Jakarta Stock Industrial Classification (JASICA). The agricultural sector has the most significant effect of earning volatility on cost debt costs among the other sectors. Hasan and Quibria (2004) find that agriculture growth is significant in reducing poverty in South Asia and Sub Saharan Africa, while industrial sector growth is the driver of poverty reduction in East Asia. Suryahadi, et. al. (2009) found that the location and sectoral components of growth do matter for the impact of economic growth on poverty reduction; not all sectoral components of economic growth contribute equally to poverty reduction. Given that most of the poor in Indonesia are located in rural areas, identifying sectoral growth that would significantly reduce rural poverty is the first priority. Growth in urban services sector has the highest impact on reducing rural poverty, followed by growth in rural agriculture. From year to year the performance in the agricultural sector continues to increase and even has given a very good contribution to Indonesia's economic growth and reduce the poverty. Based on the results of Badan Pusat Statistik (BPS) survey related to economic growth in the second quarter of 2018, agriculture's contribution to the rate of growth of gross domestic product (GDP) reached 13.63 percent. It means that agricultural sector in Indonesia is the main sector in Indonesia. Therefore, the agricultural sector has the most significant EBIT and EBITDA volatility on cost of debts.

\section{CONCLUSION AND RECOMMEN- DATION}

This research is aimed to examine the effect of earnings volatility on borrowers' cost of debt in all industries listed in Indonesian Stock Exchange, except the financial sector. Based on the results, earnings volatility has positive effect on borrowers' cost of debt. Furthermore, there is a significant difference between associations of earnings volatility with cost of debt for different industrial sector. Earnings volatility has positive effect on the borrowers' cost of debt so it is expected that every company have to maintain their earnings stability. Earnings can be stable if the company have a good performance to generate good profitability. In addition, there are differences in the effect of earnings volatility that occurs in each industry sector in Indonesia. The result can differentiate effect of earnings volatility on cost of debt across industrial sectors so all of it can improve its financial performance and earnings quality.

There are some limitations in this research. There are nine control variables used by Huq (2016), but this research did not use all of the control variables but only three control variables were chosen to have the most relevant relationship on cost of debt. The small number of control variables is one of the limitations in this research which causes the research results being less significant with the results of previous research. The future research can use all of control variables and include the financial and banking industry as the sample to know the effect of earning volatility on cost of debt both lenders and borrowers side. 


\section{REFERENCES}

Atmaja, L. S. (2008). Teori dan praktek manajemen keuangan. Yogyakarta: Andi Offset.

Aslan, H., \& Kumar, P. (2012). Strategic ownership structure and the cost of debt (25). New York: The Review of Financial Studies.

Bharath, S. T., Sunder, J. \& Sunder, S. V. (2008). Accounting quality and debt contracting. The Accounting Review, 83 (1), 1-28.

Bhattacharya, N., Desai, H., \& Venkataraman, K. (2015). Does earnings quality affect information asymmetry: Evidence from trading costs. Singapore: Research Collection School Of Accountancy, Singapore Management University.

Baxter, N. D. (1967). Leverage, risk of ruin and the cost of capital. The Journal of Finance, 22 (3), 395-403.

Beidleman, C. R. (1973). Income smoothing: The role of management. The Accounting Review 48, 653-667.

Billett, M., Hribar, P., \& Liu, Y. (2015). Shareholder-manager alignment and the cost of debt. SSRN: https://ssrn.com/abstract=958991 or http://dx.doi.org/10.2139/ssrn.95899 1.

Cameron, A. C., \& Trivedi, P. K. (2009). Microeconometrics: Methods and application $\left(8^{\text {th }}\right.$ Ed.). Cambridge, England: Cambridge University Press.

Chang, H., Fernando, G. D., and Liao, W. (2009). Sarbanes Oxley Act, perceived earnings quality and cost of capital, Review of Accounting and Finance, 8 (3), 216-231.
Cohen, D. (2003). Quality of financial reporting choice: Determinants and economic consequences. Working Paper of Northwestern University Collins.

Dichev, I. D., and Tang, V. W. (2009). Earning's volatility and earnings predictability. Journal of Accounting and Economics (47), 160-181.

Garcia-Teruel, P. J., Martinez-Solano, P., and Sanchez-Ballesta, J. P. (2014). Supplier financing and earnings quality. Journal of Business Finance \& Accounting, 41 (9 and 10), 11931211.

Gassen, J., \& Fulbier, R. U. (2015). Do creditors prefer smooth earnings? evidence from european private firms. Journal of International Accounting Research, 14.

Han, S. (2010). A cross-country study on the effects of national culture on earnings management. Journal of International Business Studies (41).

Hasan, R., \& Quibria, M. (2004). Industry matters for poverty: a critique of agricultural fundamentalism. Kyklos, 57.

Houqe, M., Kerr, R., \& Monem, R. (2013). Business strategy and earnings quality. SSRN.

Huq, A. M. (2016). Effect of earnings volatility on cost of debt: the case of swedish limited companies. Falun: Dalarna University.

Jusup, A. (2001). Dasar-dasar akuntansi $\left(2^{\text {nd }}\right.$ Ed). Yogyakarta: STIE YKPN.

Khan, S., \& Bradbury, M. E. (2014). Volatility and risk relevance of comprehensive income. Journal of Contemporary Accounting \& Economics, 10, 76-85. 
Mansi, S., Maxwell, W., \& Miller, D. (2011). Analyst forecast characteristics and the cost of debt. SSRN.

Masri, I., \& Martani, D. (2012). Pengaruh tax avoidance terhadap cost of debt. Proceeding at Simposium Nasional Akuntansi XV Banjarmasin.

Minton, B. A., \& Schrand, C. (1999). The impact of cash flow volatility on discretionary investment and the costs of debt and equity financing. Journal of Financial Economics, 54, pp. 423-460.

Nurauliawati, H. (2010). Analisis kinerja perusahaan industri telekomunikasi dengan metode economic value added (Periode 2006-2009). Jakarta: Universitas Indonesia.

Pagalung, G. (2012). The determinant factors of earnings quality and economic consequences. Jurnal Ekonomi dan Keuangan Vol.16 (1).

Prevost, A. K., Rao, R. P., \& Skousen, C. J. (2008). Earnings management and the cost of debt. SSRN: https://ssrn.com/abstract $=1083808$ or http://dx.doi.org/10.2139/ssrn.10838 08 .

Sekaran, U., \& Roger, B. (2013). Research methods for business: A skillbuilding approach (6th Ed). United Kingdom: John Wiley \& Sons Ltd.

Siallagan, H., \& Mas'ud, M. (2006). Mekanisme corporate governance, kualitas laba dan nilai perusahaan. Proceeding at Simposium Nasional XI, Padang.
Suryahadi, A., Suryadarma, D., \& Sumarto, S. (2009). The effects of location and sectoral components of economic growth on poverty: Evidence from Indonesia. Journal of Development Economics, 89.

Soderstrom, N., Jung, B., \& Yang, Y. (2012). Earnings smoothing activities of firms to manage credit ratings. Contemporary Accounting Research.

Torres-Reyna, Oscar. 2007. Panel Data Analysis Fixed and Random Effects using Stata (v.4.2). New Jersey: Princeton University. Retrieved from http://dss.princeton.edu/training/

Trueman, B., \& Titman, S. (1988). An explanation for accounting income smoothing. Journal of Accounting Research, 26.

Van B J., Graham, J. R., and Yang, J. (2010). The cost of debt. The Journal of Finance, 65, 2-30.

Wasiuzzaman, S., Sahafzadeh, I., \& Rezaie, N. (2015). Prospect theory, Industry Characteristics and Earnings Management. Review of Accounting and Finance, 14. 